\title{
Long-term affected energy production of waste to energy technologies identified by use of energy system analysis
}

\author{
Münster, Marie; Meibom, Peter
}

Published in:

Waste Management

Link to article, DOI:

10.1016/j.wasman.2010.04.015

Publication date:

2010

Document Version

Peer reviewed version

Link back to DTU Orbit

Citation (APA):

Münster, M., \& Meibom, P. (2010). Long-term affected energy production of waste to energy technologies identified by use of energy system analysis. Waste Management, 30(12), 2510-2519.

https://doi.org/10.1016/j.wasman.2010.04.015

\section{General rights}

Copyright and moral rights for the publications made accessible in the public portal are retained by the authors and/or other copyright owners and it is a condition of accessing publications that users recognise and abide by the legal requirements associated with these rights.

- Users may download and print one copy of any publication from the public portal for the purpose of private study or research.

- You may not further distribute the material or use it for any profit-making activity or commercial gain

- You may freely distribute the URL identifying the publication in the public portal

If you believe that this document breaches copyright please contact us providing details, and we will remove access to the work immediately and investigate your claim. 


\title{
Long Term Affected Energy Production of Waste to Energy Technologies Identified by Use of Energy System Analysis
}

\author{
M. Münster* and P. Meibom
}

Risoe National Laboratory for Sustainable Energy -Technical University of Denmark, Frederiksborgvej 399, 4000 Roskilde, Denmark

*E-mail: maem@risoe.dtu.dk. Tel: +45 46775166. Fax: +45 46775199 



\section{ABSTRACT}

Affected energy production is often decisive for the outcome of consequential life cycle assessments when comparing the potential environmental impact of products or services. Affected energy production is however difficult to determine. In this article the future long-term affected energy production is identified by use of energy system analysis. The focus is on different uses of waste for energy production. The Waste-to-Energy technologies analysed include co-combustion of coal and waste, anaerobic digestion and thermal gasification. The analysis is based on optimization of both investments and production of electricity, district heating and bio-fuel in a future possible energy system in 2025 in the countries of the Northern European electricity market (Denmark, Norway, Sweden, Finland and Germany). Scenarios with different $\mathrm{CO}_{2}$ quota costs are analysed. It is demonstrated that the waste incineration continues to treat the largest amount of waste. Investments in new waste incineration capacity may, however, be superseded by investments in new Waste-to-Energy technologies, particularly those utilising sorted fractions such as organic waste and refuse derived fuel. The changed use of waste proves to always affect a combination of technologies. What is affected varies among the different Waste-to-Energy technologies and is furthermore dependent on the $\mathrm{CO}_{2}$ quota costs and on the geographical scope. The necessity for investments in flexibility measures varies with the different technologies such as storage of heat and waste as well as expansion of district heating networks. Finally, inflexible technologies such as nuclear power plants are shown to be affected.

\section{Keywords}

Waste-to-Energy technologies, energy system analysis, long term marginal energy production, consequential LCA 


\section{Introduction}

Due to demands for reduction in $\mathrm{CO}_{2}$ emission and a subsequent increase in renewable energy, the European countries are aiming for significantly increased amounts of wind in the national energy systems. In order to facilitate this, higher flexibility is required from the remaining energy system. Denmark is an interesting case with up to $20 \%$ of the electricity coming from wind power. Currently a high percentage of waste is incinerated in combined heat and power (CHP) plants which contribute $5 \%$ of the electricity production and $20 \%$ of the heat production (Danish Energy Agency 2008). Albeit this is preferable to disposal at landfills the system is inflexible as only minor, dry parts of the waste can be stored for more than a week e.g. in piles or bales and that at considerable costs. Due to these circumstances, the incineration must take place continuously which results in heat being produced at times where the demand is low. This leads to large amounts of heat ( $8 \%$ of the heat production from waste) being cooled off, particularly during summertime (Danish Energy Authority 2008). Alternative uses of waste for energy production may well improve energy efficiency and allow for increased shares of wind energy in the system. An important aspect of the analysis is the potential of producing bio-fuels from waste, thereby counteracting the present inflexibility of the heat and electricity production by the CHPs.

Up to now, comparisons of Waste-to-Energy (WtE) technologies have primarily been carried out by applying life cycle assessment (LCA) approaches (Baky \& Eriksson 2003; Cherubini et al. 2008; Eriksson et al. 2007; Finnveden 1999; Kirkeby et al. 2006). LCA's can be either attributional - measuring the "footprint" of a product or service - or they can be consequential - measuring the potential impact of a change. Whereas average data generally are 
used for attributional LCA's - marginal ${ }^{1}$ data are used for consequential LCA's, illustrating the significance of an infinitesimal change. It may be attempted to identify the marginal energy production in the short term ${ }^{2}$ by analyzing which plants have surplus capacity and the potential for reacting to changes in production or consumption. Energy System Analysis (ESA) may, however, contribute to identifying the affected energy production even in a long term as it is possible to capture the significance of increased flexibility in the long term with models, which incorporate the dynamic properties of the energy system. Furthermore, it is possible with some ESA models to use a normative approach and simulate scenarios while keeping track of energy flows. Other ESA models e.g. Balmorel (Ravn 2001) may also use an explorative approach making it possible to optimize future energy systems. This may be done by allowing the models to find optimal solutions for supplying the requested amounts of energy at the required hours e.g. in the most cost-efficient way.

Energy system analysis of WtE technologies have formerly been conducted by Münster and Lund (Münster \& Lund 2008; Münster \& Lund 2009) where different ways of using waste for energy production were compared. For this task, a national energy system analysis was applied which optimizes the production of energy in the energy system using analytically/ strategically based optimisation. The studies showed good potential for thermal co-gasification and anaerobic digestion. They did, however, also illustrate that assumptions regarding the affected electricity production plant are crucial for determining the environmental consequences when trading with the surrounding countries. Furthermore, reviews of a wide range of LCAs underline the importance of affected energy production on the results of the potential environmental impacts (Finnveden et al. 2007; Sundberg et al. 2004; Villanueva \& Wenzel 2007; Winkler \& Bilitewski

\footnotetext{
${ }^{1}$ An effect may be defined as "marginal” if the effect of a decision on the total production volume of a product is small enough to be approximated as infinitesimal. LCA's often contribute to political decision making regarding the future. As effects of long term changes in the future use of waste for energy may not be infinitesimal - and hence not "marginal" - the term "affected" is deemed more relevant, although the term "marginal" is more often used.

${ }^{2}$ A short-term effect refers to change in production. A long-term effect refers to change in capacity.
} 
2007).

Only few energy system analyses (ESAs) have been made of the Waste-to-Energy technologies. These use load duration curves and focus either on district heating systems or on national electric energy systems (Cosmi et al. 2000; Holmgren \& Henning 2004; Knutsson et al. 2006; Ljunggren Soderman 2003; Sahlin et al. 2004; Salvia et al. 2002). Use of load duration curves, however, does not make it possible to fully take into account the dynamic properties of the energy technologies due to the loss of chronological time. Particularly technologies which add flexibility to the energy system, such as storage technologies, are not given fair judgment. The ESAs are all performed on the current energy system or with a short-term view into the future. The only Waste-to-Energy (WtE) technology analysed is waste incineration.

The purpose of this study is to show advantages of identifying long-term affected energy production with ESA through a theoretical discussion and a case study of the Northern European electricity market (Denmark, Finland, Germany, Norway and Sweden) using Balmorel to generate cost optimal future combinations of power generation, storage and transmission technologies.

In the subsequent sections it is first discussed how to identify affected energy production and recommendations are made, based on review of three articles. Subsequently the Balmorel model used for the case study is presented as well as the technologies and main assumptions of the analysis. In the last sections the results are presented and conclusions are made with regard to the affected energy production.

\section{Identifying affected energy production}

In this section recommendations of how to identify long-term affected energy production are found through theoretical discussions of three different articles. The recommendations are to be tested in the following case study. 
Energy system analysis (ESA) can be used to identify affected energy production. ESA is used particularly to assess the impact of changes in energy production on e.g. national energy systems. This is an aspect which other assessment methods fail to address substantially. ESA focuses on one step of the life cycle (energy conversion), with simulation of all the interacting energy technologies rather than focusing on one or two technologies during the full life cycle. The full life cycle is normally defined as the phases from waste generation to final disposal in the case of waste LCAs.

In 2007, Ekvall, Assefa, Björklund, Eriksson and Finnveden discussed the fact that "a traditional LCA model has several inherent characteristics which prevent it from giving adequate answers to many significant questions" in the article "What life-cycle assessment does and does not do in assessments of waste management”(Ekvall et al. 2007). A number of issues are raised:

1. With regard to the functional unit it is identified as problematic when static assumptions regarding the waste amount are employed and e.g. one tonne of waste is used as the functional unit. An amendment to this might be to have the amount of waste produced in an area as the functional unit, thus making it possible to include waste reduction as a strategy.

2. Along the same line, the system dynamics is considered problematic as traditional LCA models do not provide answers to how much waste treatment capacity is needed. The static nature is criticized further: "Perhaps more seriously, the system structure and the input data in a traditional LCA both reflect the recent past. This means that, at its best, traditional LCA provides basis for identifying the waste strategies best suited for solving the needs of the current society.” It is suggested to conduct studies regarding the future and to use dynamic models which may identify the appropriate time for investments.

3. Concerning spatial information, the problem is addressed that emissions have different impacts depending on where they are emitted. An amendment of this is suggested by using site-dependent modelling on regional level and by combining local studies with environmental assessment. 
4. Furthermore, information on specific pollutants is addressed as is the practice of aggregating substances of the same type using sum parameters since the environmental impacts of these substances may vary greatly. It is suggested to avoid sum parameters and use specific data when possible.

5. Regarding non-linear relationships, the problem is addressed that LCA models are linear while the reality may be nonlinear. As amendment to this, it is suggested to apply linear programming with partially linear functions.

6. With regard to effects on background systems, it is considered a problem in the article that average data are often used for effects on energy systems and production of materials and fertilizers. It is recommended to identify long-term marginal effects using dynamic optimizing models.

7. Concerning inclusion of non-environmental impacts it is recommended to combine or supplement analyses with e.g. cost benefit analysis. Pros (such as simple answers or transparency) and cons (such as lack of information) for the two approaches are discussed.

Combining LCA with ESA may alleviate some of the inherent problems. Particularly with regards to points 2 and 6 ESA may have something to offer, as future studies are made possible by using dynamic modelling and by identifying long-term affected energy production. This can be done with linear programming with piecewise linear functions, reference to point 5 . The ESA modelling district heating systems include spatial data. This makes it possible to address point 3 by identifying in broad terms the areas in which an investment in a WtE technology would be most feasible.

Although ESAs in general do not include non-energy waste treatment and tend to leave out waste prevention in particular, it is uncomplicated to perform analyses of scenarios with different waste amounts such as shown in Münster and Meibom (2009), which addresses point 1. Furthermore, if non-energy treatments are represented by prices it will be possible to include 
these technologies in the optimization. In doing so, the waste amounts could be allocated to where it would be most economically feasible.

Apart from improving the assessment of environmental impacts, ESA may also improve assessment of non-environmental impacts by estimating when and where and in which technologies investments may occur (point 7). It may be possible to combine LCA with ESA in one model, but as both types of models are complex and require extensive training, practice and data collection, it is here recommended to keep the models apart. If cooperation between the models is judged necessary, manual iterations between the models are recommended. ESAs normally only include $\mathrm{CO}_{2}$ emissions and possibly also methane, sulphur and NOx but they may be extended to include more emission factors, which LCAs show to be important - or results from ESAs may be included in LCAs in which affected energy production may be decisive for the results.

In Ekvall \& Weidema (2004) 5 steps are presented to identify a marginal technology:

1. Firstly, the relevant time aspect is discussed. It is argued that "In reality, any change can be expected to have a combination of short term and long term effects.” In energy terms shortterm effects refer to changes in production and long-term effects refer to changes in capacity.

2. Secondly, the relevant markets must be identified and "If the decision influences a market it is necessary to identify the marginal technology of this market.” In energy system terms, markets may be electricity or district heating markets. As an established electricity market exists among e.g. the Nordic countries and Germany, affected energy technologies may be found in these countries rather than in Denmark. One example of this is expansion of Danish wind power production that might lead to reduction in coal or natural gas based power production either in Denmark, Finland or Germany dependant on the relative competiveness of the fossil based power plants in these countries.

3. Thirdly, it is necessary to "identify the overall trend in the demand on the relevant market segment" and "the replacement rate of existing production capacity". Hence, it is important to 
assess the trend with regard to demand for electricity and heat and decommissioning of existing plants. Furthermore the waste amounts available for energy production must be assessed.

4. Fourthly, the flexibility of technologies must be assessed. This argument is often used to discard wind or hydropower as marginal technologies. In the short term, technologies which are affected by a change must be able to adjust the production and in the long term, technologies must be able to adjust capacity. When looking at an energy system in the long term, all types of energy technologies may in practice be flexible in terms of either production or capacity and should therefore be included in an analysis. Natural, political and market constraints are mentioned as important, but these are often not fixed entities and may change e.g. as technologies develop.

5. Finally, the marginal technology is said to be determined by the short term or long term cost per unit, depending on whether the technologies are to be phased out or installed.

(Ekvall \& Weidema 2004)

ESAs may be conducted either with a short-term perspective optimising only production or with long-term perspective including both investments and production in the optimisation. Often optimisations are done with focus either on heat markets or on electricity markets, maybe representing the heat markets as just one aggregate district heating area. For the near future ESAs, current data regarding energy demand and waste production are used, whereas it is a necessary part of all ESAs of future scenarios to estimate the trends in this respect. When modelling energy systems, all technologies in the respective systems will be represented regardless of their short-term or long-term flexibility. Energy system models optimizing production and investments will normally do that according to both short-term and long-term costs and are hence constructed using the same assumptions as mentioned above.

Mathiesen et al. (2009) illustrate problems in the current practise of identifying "marginal” energy technologies. As illustrated in the article through a review of current consequential 
LCAs, one single technology, either a coal or natural gas fired CHP plant is in general assumed to be the "marginal” energy production plant. The "marginal” energy production plant is chosen, based on a range of varying arguments, but only in one case does energy system analysis form part of the identification. Furthermore, the final recommendations of the article are based on a historical analysis of the "marginal” energy production technology in Denmark and on an energy system analysis of increased waste incineration. In the energy system analysis waste incineration is increased in different district heating areas, in different energy systems and with different flexibility. The energy system analysis in the article shows great differences with regard to fuel substitution in the different scenarios. Based on the three types of analyses, three recommendations for identifying "marginal” energy technologies are presented (Mathiesen et al. 2009):

- Use fundamentally different affected technologies, including production technologies unable to adjust to changes in demand, such as wind;

- Use long-term perspectives by identifying affected technologies in several possible and fundamentally different future scenarios, i.e. both fossil and renewable energy technologies; and

- Identify the affected technologies on the basis of energy system analysis taking into account the technical characteristics of the technologies and the energy system involved.

The first and third recommendations follow logically when performing a national energy systems analysis. The second recommendation relates to the time perspective and to trends. As illustrated in the above mentioned article, energy technologies perform differently in different energy systems and hence, in order to evaluate the technology, it is necessary to perform energy system analysis of WtE technologies not only in current energy systems, but also in medium and long-term future energy systems. In an LCA context the significance of doing this has also been illustrated by Klang et al. (Klang et al. 2008). 
Based on the above three articles the following five recommendations can be made when identifying long-term affected energy production:

1. Identify affected energy production with energy system analysis

2. Include the full electricity market in the analysis along with local district heating markets

3. Optimize both investments and production according to costs

4. Include investments in both flexible and inflexible energy production technologies, as well as storage technologies in the optimisation

5. Analyse fundamentally different future scenarios

In the following sections these five recommendations are tested through an energy system analysis of Danish WtE technologies in a Northern European electricity market.

\section{Energy System Analysis Model}

The energy system analysis is performed in Balmorel, which is a linear optimization model that optimizes investments as well as production with regard to electricity and heat production and also storage and transmission. The model is open source and is available at the model homepage along with documentation and examples of use. A GAMS license and linear programming software is required to run the model (Ravn 2009).

The model incorporates several countries participating in an electricity market. Each country is divided into one or several regions between which electricity is traded, restricted by electricity transmission capacity. Each region is divided into one or several district heating areas between which no heat may be traded. The model has flexible time division modelling a year divided into seasons (e.g. 52 weeks) and time periods (e.g. 168 hours). By running hour-by-hour as opposed to using load duration curves, the model maintains the chronology of demand and production, and it facilitates modelling of e.g. short-term energy storage. In the analysis presented in this article, it has been necessary to settle for 4 seasons and 168 time periods. Thereby hourly representations of one week for each season are achieved. The Balmorel model 
has been applied to a wide range of countries analysing a broad spectrum of technologies as well as market conditions (Ball et al. 2007; Jensen \& Meibom 2008; Karlsson \& Meibom 2008).

\section{Technologies and main assumptions}

The technologies and energy system analysed in this article are the same as used to identify the most economically optimal combination of $\mathrm{WtE}$ technologies in a range of different scenarios in Münster and Meibom (2009). The most important inputs to the model are described below, but further explanations of the technologies and documentation of the assumptions may be found in the article (Münster \& Meibom 2009).

In order to identify the affected energy production, the technologies are analysed separately in this article. The technical alternatives are thus analysed by allowing investments in waste incineration as well as in each type of WtE technologies in turn in Denmark. Subsequently the model calculates optimal utilisation between CHP or transport fuel, or between upgrading existing plants or building new in the case of Co-combustion. Apart from in Denmark, waste is incinerated. The same amount of waste is used in all alternatives, apart from the Less Waste alternative, where the use of waste for energy production is decreased by 1 PJ. Refuse derived fuel (RDF) mainly consists of dry paper, plastics and wood and organic waste consists of mainly wet food waste. To show the effects of the optimal combination a combined alternative is also analysed. The alternatives are listed below:

- Incineration: Existing and new waste incineration CHP (Mixed waste)

- Co-combustion: Upgraded and new co-combustion plants (Coal and RDF)

- Biogas: Biogas for CHP or transport fuel (Organic waste and manure)

- RDF gas: Thermal gasification for CHP or transport fuel (RDF)

- Syngas: Syngas for CHP and transport fuel (Mixed waste and coal)

- Combined: All WtE technologies

- Less waste: 1 PJ less waste in Incineration alternative 
The efficiencies and costs (given in EUR 2007) of the WtE technologies along with the waste fractions and additional fuels are illustrated in Table 1. The different WtE technologies can utilise different sorted waste fractions, but all can be incinerated. Apart from incineration, mixed waste can only be used for co-gasification with coal. Organic waste is used in biogas plants, and RDF is used both for thermal gasification and for co-combustion with coal.

For extraction plants, which can vary the ratio between electricity and heat production, the fuel efficiency illustrates the electrical efficiency. For the remaining plants, it illustrates the total fuel efficiency. The back-pressure coefficient (CB) is the ratio between power generation and district heat generation in back-pressure mode. The CV-value for an extraction steam turbine is the reduction in power generation in MWh associated with increasing district heat generation by one MWh while keeping the fuel consumption constant. For some plants the variable operation and maintenance (O\&M) costs are included in the fixed O\&M costs.

Table 1 Efficiencies and costs of WtE technologies

Further energy technologies, in which the model is allowed to invest, encompass biomass and fossil fuelled condensing and CHP plants as well as nuclear plants. Furthermore, investments are allowed in wind power, heat boilers, heat pumps, heat storage, electricity transmission and new district heating networks (Münster \& Meibom 2009).

The fuel prices, lower heating values and fossil CO2 content assumed are illustrated in Table 2. The oil price is equivalent to $119 \mathrm{USD} / \mathrm{bbl}$ It is assumed that plants will receive payment for treating mixed waste and organic waste equal to $3 \mathrm{EUR} / \mathrm{GJ}$, whereas RDF is treated for free. Manure is assumed to be available from outside the energy system at no cost. Currently, only $10 \%$ of the Danish manure resource is treated at biogas plants. Furthermore, it is assumed that organic waste equivalent of $4 \%$ of the mixed combustible waste may be sorted out and used for biogas production (Fruergaard 2008). For RDF the equivalent figure is 19\% (Ramboll 2008). Finally, it is assumed possible to store $40 \%$ of the mixed combustible waste for six months. 
Table 2. Projected fuel prices in 2025, lower heating values and $\mathrm{CO}_{2}$ content of fuels

In order to find the most likely affected energy production it would be beneficial to include all energy related taxes, subsidies and regulations in all the modelled countries in 2025. These are, however, extremely difficult if not impossible to estimate. As the objective of this article is to identify the plausible mechanisms behind the affected energy production, it is here assumed that the most important externality to include are the $\mathrm{CO}_{2}$ emissions. As $\mathrm{CO}_{2}$ emissions are traded on a European market with global interactions through CDM projects, different prices are assumed for $\mathrm{CO}_{2}$ quotas as is the case with fuels traded on the global market. The $\mathrm{CO}_{2}$ quota price is expected to be $32 \mathrm{EUR} / \mathrm{t}$ in the high scenario and in the low $\mathrm{CO}_{2}$ quota price scenario the price is only assumed to reach 25 EUR/t (Danish Energy Authority 2009).

As a result of the energy system analysis the percentage of renewable energy in the energy system analysed reaches $43 \%$ in Denmark, mainly due to a high contribution from wind. The assumed energy demands and electricity production capacity are shown in Table 3. The expected demands are taken mainly from Eurelectric and from the Danish Energy Authority. The electricity production capacities shown are the capacities which are assumed to remain after decommissioning if no investments are made in the period until 2025. The sizes as well as the main energy sources are illustrated for each country.

Table 3. Projected energy demands and remaining electricity production capacity in the Nordic countries and Germany

\section{Results}

After having presented the main assumptions in the former section, this section describes the results of the energy system analysis. The alternatives are compared in terms of:

- Use of waste for energy in different $\mathrm{WtE}$ technologies

- Fuel consumption 
- Flexibility measures (Heat and waste storage and expansion of heat and electricity transmission)

- $\mathrm{CO}_{2}$ emissions

- Total yearly costs of the energy system

The changed use of waste as a resource for energy production in different types of $\mathrm{WtE}$ plants is illustrated in Figure 1. Generally most of the waste continues to be incinerated regardless of the possible investments in new WtE technologies as shown in the left axis. In the Co-combustion alternatives most, but not all RDF is used. Co-combustion of RDF with coal mainly takes place in new coal-fired power plants, but upgrade of existing plants is also found in plants with high total efficiencies. Furthermore, increased operation and maintenance costs combined with costs of upgrading as well as decreased electrical efficiencies limits the upgrading. On the other hand co-combustion in new plants is correlated with the demand for new coal-fired power plants in general.

In the Biogas alternatives the full amount of organic waste is sorted out and used. The model chooses to use the biogas for CHP in the scenario with high CO2 prices and to use it for transport fuel in the scenario with low CO2 prices. This is due to the fact that when using biogas to replace fuels for heating or electricity production, costs of $\mathrm{CO}_{2}$ quotas are reduced in these plants as they form part of the $\mathrm{CO} 2$ quota system. This is not the case when replacing transport fuels.

In the RDF gasification alternatives the full amount of RDF is sorted out and used for CHP in both scenarios. Investments in Syngas, where waste is co-gasified with coal, are only found with the low $\mathrm{CO}_{2}$ price, where it is mainly used for transportation. The reason for this is that the $\mathrm{CO}_{2}$ emissions increase in the Syngas alternative due to increased use of coal.

Combined alternatives, in which the model optimizes among choices of investments in all WtE plants, have investments in a combination of all new WtE technology types. These are also 
the alternatives where the full potentials of organic waste and RDF are used, where least waste is used for waste incineration and where the investments in new WtE technologies exceed the investment in new waste incineration capacity. Competition for RDF is seen in the Combined alternatives between the co-combustion plants and RDF gasification plants. Of the two technologies, co-combustion of waste with coal is the most developed, and RDF gasification may be more relevant in a longer time horizon as is the case with gasification of mixed waste in the syngas plant.

Figure 1. Use of waste for energy in Denmark. Waste CHP is shown on the left axis and the remaining WtE technologies on the right

When comparing with the incineration alternative, the differences with regard to fuel use vary in Denmark as shown in Figure 2. The main change in use of fuel is seen in the Cocombustion alternatives, where the use of coal increases by respectively $30 \mathrm{PJ}$ and $51 \mathrm{PJ}$ in the high and low $\mathrm{CO}_{2}$ price scenarios. With the possibility of using RDF as free fuel, coal-fired CHP becomes more feasible and investments in coal-fired CHP increase in Denmark from 900 MW to 2150 MW, thereby replacing investments in nuclear power capacity in Sweden. For most alternatives large effects are seen abroad, as seen when comparing with Figure 3. Owing to investments in a syngas plant in the low $\mathrm{CO}_{2}$ price scenario, the use of biomass decreases in existing biomass co-combustion plants in the area where the investments are made. With different fuel prices, different effects would be seen.

Figure 2. Changed fuel use for Denmark concerning all technologies, when compared to the Incineration alternative with high or low $\mathrm{CO}_{2}$ prices respectively (max $20 \mathrm{PJ}$ shown)

When looking at the affected fuel use in the whole region shown in Figure 3, the general picture is that use of coal increases while nuclear power decreases. The most significant effects 
are again seen in the Co-combustion alternatives, where coal increases with $20 \mathrm{PJ}$ and $36 \mathrm{PJ}$ in the high and low $\mathrm{CO}_{2}$ quota price scenarios respectively, while use of uranium decreases simultaneously by $36 \mathrm{PJ}$ and $65 \mathrm{PJ}$. The reason for this is that using free RDF as supplementary fuel makes coal fired plants more competitive than some nuclear plants.

Figure 3 Changed fuel use for the whole region for all technologies, when compared to the Incineration alternative with high or low $\mathrm{CO}_{2}$ prices respectively (max $15 \mathrm{PJ}$ and min -30 PJ shown)

Significant changes are seen in the use of nuclear power, but as construction of new nuclear plants is heavily affected by political decisions, it is relevant to do a sensitivity analysis without the possibility of investing in new nuclear facilities. When doing this for the Incineration alternative with the high $\mathrm{CO}_{2}$ price, a substantial increase in coal consumption and wind power utilisation is found. When allowing for investments in new WtE technologies, the effect in Denmark is increased use of coal in co-combustion plants and a decrease in wind power. In the whole region the effect is a small reduction in the production from coal, wind power and lignite, because the waste is used more efficiently. The total figures for the Incineration alternatives and the differences with the remaining alternatives are shown in Table 4.

Table 4 Fuel use in the whole region. Totals for Incineration alternatives and differences compared to these for the remaining alternatives.

For all alternatives a mix of fuels is affected as seen in Figure 4. Furthermore, it is noteworthy that for the whole region, effects are seen on nuclear power or wind power, which are inflexible technologies in terms of capability to react to short-term changes in demand but not to long-term changes in capacity. Generally, inflexible production technologies are not considered, when LCA practitioners determine the "marginal” energy production.

The need for flexibility measures differs when allowing investments in different WtE 
technologies as shown in Figure 4. Overall, the use of waste storage decreases as production becomes more flexible and less linked to heat demand. The expansion of new district heating networks is virtually the same in all alternatives, apart from the Co-combustion alternative in the low $\mathrm{CO}_{2}$ price scenario, where a larger expansion is seen. Here the need for central waste storage decreases and the electricity and heat productions increase significantly reducing the need for import of electricity, and thereby the need to expand electricity transmission. However, an increased need both for new district heating networks and for heat storage is found. In the Cocombustion alternative with high $\mathrm{CO}_{2}$ costs, less increase in Danish production is seen and consequently, the slight increase in district heating networks reduces the need for heat storage.

The results show that it would not be sufficient to aggregate all district heating grids into one, as illustrated by the changes concerning heat storage and expansion of district heating networks. This is due to the fact, that these flexibility measures would not be necessary when assuming that heat can be transferred freely among the many district heating networks.

Figure 4. Changes in new DH consumption owing to investments in DH networks, electricity transmission and heat storage as well as use of central waste storage compared to the Incineration alternative.

Table 5 shows the changed $\mathrm{CO}_{2}$ emissions compared to the incineration alternatives. The most significant change is increase of $\mathrm{CO}_{2}$ emissions in the Co-combustion alternatives due to increased use of coal. For most alternatives, the $\mathrm{CO}_{2}$ emissions increase compared to waste incineration. Decreases are only seen when biogas is produced for transport fuel in a low $\mathrm{CO}_{2}$ price scenario and when less waste is used for energy production in a situation with high $\mathrm{CO}_{2}$ prices. Overall, an increase in $\mathrm{CO}_{2}$ emissions in Denmark is followed by increased $\mathrm{CO}_{2}$ emissions in the whole region.

When, concerning the yearly costs of the total energy system of the whole region, the 
comparison is made between the Incineration alternative and the other alternatives, savings are found in all alternatives apart from Syngas in the high $\mathrm{CO}_{2}$ cost scenario, as shown in Table 5. No investments are therefore made in the Syngas alternative in this scenario. The largest total saving is achieved with the Combined alternatives and the largest saving per PJ waste moved are found in the Biogas alternatives.

Table 5 Changed $\mathrm{CO}_{2}$ emissions and changed costs compared to the Incineration alternative

\section{Conclusion}

In all scenarios by far the largest amount of waste is treated with waste incineration but investments in new waste incineration capacity may be superseded by investments in new $\mathrm{WtE}$ technologies, particularly using sorted fractions. When allowing investments in new $\mathrm{WtE}$ technologies it is feasible to move some waste from waste incineration to other WtE technologies in all scenarios apart from the "Syngas" alternative in the high $\mathrm{CO}_{2}$ price scenario. The full potential for sorting out the organic waste fraction is utilized in the Biogas alternatives and for RDF it is fully utilized with gasification for CHP production. Mixed waste is only used in a new WtE technology (Syngas) in the scenario with low $\mathrm{CO}_{2}$ costs.

The only two alternatives which provide $\mathrm{CO}_{2}$ reductions in the conversion stage are when the Biogas alternative produces transport fuel and when less waste is used in the high $\mathrm{CO}_{2}$ price scenario. Out of the two, the lowest emissions are obtained in the Biogas alternative. The two alternatives have the lowest $\mathrm{CO}_{2}$ emissions, both when looking at Denmark or the whole region. If considering the whole life cycle, the results for biogas would be even better due to codigestion of manure.

The affected fuel consumption consists of a mix of fuels in all cases and depends on the $\mathrm{CO}_{2}$ price, the technology and the region in question. In Denmark the main fuel affected is coal, 
the use of which increases. When looking at the whole region, the main fuel affected is uranium, the use of which decreases. In a system without new investments in nuclear or in new WtE technologies, more wind enters the system. This amount, however, decreases slightly when allowing investments in new $\mathrm{WtE}$ technologies. With other fuel and investment prices, the results would change.

When comparing use of waste for energy with other types of waste treatment, one should be aware that reducing the amount of waste for energy may result in either decreased or increased $\mathrm{CO}_{2}$ emissions, depending on the $\mathrm{CO}_{2}$ quota costs. However, in both scenarios it has the benefits of reducing the costs of the energy system as well as reducing waste storage.

Overall, the use of waste storage decreases when allowing investments in new WtE technologies. Expansion of the district heating networks changes little among the different alternatives apart from the Co-combustion alternative with low $\mathrm{CO}_{2}$ price, where a significant increase is shown. The highest amount of heat storage is also found here. Furthermore the Cocombustion alternatives result in the lowest expansion of electricity transmission.

\section{Recommendations}

The question now remains whether the analysis supports the recommendations for identifying the long-term affected energy production which were brought forward in the introduction?

\section{Identify affected energy production with energy system analysis}

One single "marginal" energy production plant is normally assumed when performing LCAs. The analyses presented above consistently show that the affected energy production consists of a combination of energy technologies. By using ESA it is possible to identify the combination of affected energy technologies.

2. Include the full electricity market in the analysis along with local district heating markets

The analyses show different results with regard to affected energy production for Denmark 
and for the whole region (DK, NO, FI, SE, DE). When highly integrated markets for electricity exist, the changed energy production in one country may just as well result in effects in another country. The whole electricity market should therefore be included in the analysis. With regard to district heating the benefit of not aggregating all district heating grids into one and modelling hour by hour is illustrated by the changes in heat storage and expansion of district heating networks.

\section{Optimize both investments and production according to cost}

4. Include investments in both flexible and inflexible energy production technologies, as well as storage technologies in the optimization

The analyses show investments in "inflexible” energy technologies such as nuclear power and wind power, as well as effects on use of flexibility measures. This underlines the importance of optimizing both investment and production and of including both flexible and inflexible production technologies as well as flexibility measures in the optimization.

\section{Analyse fundamentally different future scenarios}

When reducing the $\mathrm{CO}_{2}$ quota price by only $22 \%$, quite different conclusions are found in the analyses with regard to affected technologies. As it is impossible to predict the future, it is therefore important to assess the affected energy production in different future scenarios for the energy system.

In conclusion all five recommendations have shown importance regarding the analyses presented in this article.

In future studies of life cycle assessments of the WtE it would be interesting to use the affected energy production identified in this article and make comparisons with use of single “marginal” affected energy production such as coal or natural gas fired CHP plants. As Balmorel has now been developed to simulate WtE technologies it would also be uncomplicated to make new analyses of affected energy production with other $\mathrm{WtE}$ technologies in other energy scenarios, which have been analysed with Balmorel. 


\section{ACKNOWLEDGEMENTS}

The Authors wish to thank Hans Ravn from Ram-løse edb as well as Jesper Werling, Lars Bregnbæk and Anders Kofoed-Wiuff from EA Energy Analysis for patient consulting on data and model characteristics of Balmorel. Thanks are also extended to Henrik Lund from Aalborg University and Poul Erik Morthorst for comments and discussions. Finally the Authors wish to thank Tore Hulgaard from Rambøll as well as the staff from Swedish Gas Centre, Waste Centre Denmark, DONG Energy, Danish Energy Authority, AV Miljø, KARA and L90 for contributing data to the analyses.

The paper was partially funded by the programme for strategic funding within sustainable energy administered by the Danish Technical Research Council (STVF) and is part of the research programme “'ENSUWE - Environmentally Sustainable Utilisation of Waste resources for Energy production’’.

The paper was presented in its original form at the Twelfth International Waste Management and Landfill Symposium 5 - 9 October 2009 S. Margherita di Pula, Sardinia, Italy. The authors would like to thank the audience at the conference and the reviewers for their valuable comments, which contributed to the improvements of the final version. 


\section{REFERENCES}

Ahrenfeldt, J., Bain, R. L., Beld, B. v. d. 2005, Handbook Biomass Gasification BTG biomass technology group BV.

Baky, A., Eriksson, O. Systems Analysis of Organic Waste Management in Denmark. Environmental Project no. 822, 2003. 2003. Danish Environmental Agency, Copenhagen

Ball, M., Wietschel, M., Rentz, O. 2007, Integration of a hydrogen economy into the German energy system: an optimising modelling approach, International Journal of Hydrogen Energy, vol. 32, no. 10-11, pp. 1355-1368.

Cherubini, F., Bargigli, S., Ulgiati, S. 2008, Life cycle assessment of urban waste management: Energy performances and environmental impacts. The case of Rome, Italy, Waste Management, vol. 28, no. 12, pp. 2552-2564.

Christensen, T. H., Hansen, T. L., Kirkerby, J. T., Jansen, J. l. C., Svärd, Å., Toudal, J. K., Hulgaard, T., Rasmussen, H. W., Gruvberger, C. 2003, Basisdokumentation af biogaspotentialet i organisk dagrenovation (Base documentation for the biogas potential in organic municipal waste) 802, 2003. Danish Environmental Protection Agency, Copenhagen, Denmark

Cosmi, C., Cuomo, V., Macchiato, M., Mangiamele, L., Masi, S., Salvia, M. 2000, Waste management modeling by MARKAL model: A case study for Basilicata Region, Environmental Modeling \& Assessment, vol. 5, no. 1, pp. 19-27.

Danish Energy Authority 2007, Basisfremskrivningen til CO2-kvoteallokeringsplanen for 200812 og regeringens energistrategi: En visionær dansk energipolitik. (Base Forecast for the CO2quota Allocation Plan for 2008-12 and the Energy Strategy: A Visionary Danish Energy Policy). Danish Energy Authority, Copenhagen, Denmark

Danish Energy Authority 2008a, Basisfremskrivning af Danmarks Energiforbrug frem til 2025 (Forecast of the Danish Energy Supply until 2025). Danish Energy Authority, Copenhagen, Denmark

Danish Energy Authority. Energiproducenttælling 2006 (Energy Producer Statistics 2006). 23-42008b. Danish Energy Authority, Copenhagen, Denmark

Danish Energy Authority. Guidelines in socio-economic analysis in the field of energy. 2008c. Danish Energy Authority, Copenhagen

Danish Energy Authority. Guidelines in socio-economic analysis in the field of energy. 2009. Danish Energy Authority, Copenhagen

Danish Energy Authority, ElkraftSystem, Eltra. Technology Data for Electricity and Heat Generating Plants. 2005. Danish Energy Authority, Copenhagen

DONG Energy. REnescience. 20-3-2007. Skærbæk, Denmark

Ekvall, T., Assefa, G., Bjorklund, A., Eriksson, O., Finnveden, G. 2007, What life-cycle assessment does and does not do in assessments of waste management, Waste Management, vol. 
27, no. 8, pp. 989-996.

Ekvall, T.; Weidema, B. P. 2004, System boundaries and input data in consequential life cycle inventory analysis, International Journal of Life Cycle Assessment, vol. 9, no. 3, pp. 161-171.

Eriksson, O., Finnveden, G., Ekvall, T., Bjorklund, A. 2007, Life cycle assessment of fuels for district heating: A comparison of waste incineration, biomass- and natural gas combustion, Energy Policy, vol. 35, no. 2, pp. 1346-1362.

EUCAR, CONCAWE, Joint Research Centre of the EU Commission. Well-To-Wheels Analysis Of Future Automotive Fuels And Powertrains In The European Context - WELL-to-WHEELS Report Version 2c. 2007. Joint Research Centre of the EU Commission,

Finnveden, G., Bjorklund, A., Reich, M. C., Eriksson, O., Sorbom, A. 2007, Flexible and robust strategies for waste management in Sweden, Waste Management, vol. 27, no. 8, p. S1-S8.

Finnveden, G. 1999, Methodological aspects of life cycle assessment of integrated solid waste management systems, Resources, Conservation and Recycling, vol. 26, no. 3-4, pp. 173-187.

Fruergaard, T. 2008, Assessment of waste resources for energy production - Fractions, quantities, segregation potentials and energy content. Danish Technical University, Department of Environmental Engineering, Lyngby, DK

Holmgren, K.; Henning, D. 2004, Comparison between material and energy recovery of municipal waste from an energy perspective - A study of two Swedish municipalities, Resources Conservation and Recycling, vol. 43, no. 1, pp. 51-73.

Jensen, S. G.; Meibom, P. 2008, Investments in liberalised power markets: Gas turbine investment opportunities in the Nordic power system, International Journal of Electrical Power \& Energy Systems, vol. 30, no. 2, pp. 113-124.

Karlsson, K., Meibom, P. 2008, Optimal investment paths for future renewable based energy systems--Using the optimisation model Balmorel, International Journal of Hydrogen Energy, vol. 33, no. 7, pp. 1777-1787.

Kirkeby, J. T., Birgisdottir, H., Hansen, T. L., Christensen, T. H., Bhander, G. S., Hauschild, M. 2006, Evaluation of environmental impacts from municipal solid waste management in the municipality of Aarhus, Denmark (EASEWASTE), Waste Management \& Research, vol. 24, no. 1, pp. 16-26.

Kiviluoma, J.; Meibom, P. 2009, Influence of wind power, plug-in electric vehicles, and heat storages on power system investments, Energy - the International Journal.

Klang, A. B., Vikman, P. +., Brattebo, H. 2008, Sustainable management of combustible household waste--Expanding the integrated evaluation model, Resources, Conservation and Recycling, vol. 52, no. 8-9, pp. 1101-1111.

Knutsson, D., Sahlin, J., Werner, S., Ekvall, T., Ahlgren, E. O. 2006, HEATSPOT--a simulation tool for national district heating analyses, Energy, vol. 31, no. 2-3, pp. 278-293.

Ljunggren Soderman, M. 2003, Recovering energy from waste in Sweden--a systems engineering study, Resources, Conservation and Recycling, vol. 38, no. 2, pp. 89-121.

Mathiesen, B. V., Münster, M., Fruergaard, T. 2009, Uncertainties related to the identification of 
the marginal energy technology in consequential life cycle assessments, Journal of Cleaner Production, vol. 17, no. 15, pp. 1331-1338.

Møller, J., Fruergaard, T., Riber, C., Astrup, T., Christensen, T. H. 2008, Environmental Assessment of Waste Incineration and Alternatives (In Danish). DTU Environment, Lyngby, Denmark

Münster, M., Lund, H. Use of waste for heat, electricity and transport--Challenges when performing energy system analysis. 2008. Energy In Press, Corrected Proof

Münster, M., Lund, H. 2009, Comparing Waste-to-Energy technologies by applying energy system analysis, Waste Management, vol. In Press, Corrected Proof.

Münster, M., Meibom, P. 2009, "Optimal Use of Waste in the Future Energy System," in: Münster, M. Energy System Analysis of Waste to Energy Technologies, PhD Thesis, Aalborg University, Aalborg, Denmark.

Papageorgi, A. 2006, Statistics and Prospects for the European Electricity Sector 2006-0301086. Eurelectric, Bruxelles, Belgium

Ramboll 2008, Vurdering af mængden af forbrændingsegnet affald i Danmark (Assessment of the amount of incinerable waste in Denmark) 834-071572. waste denmark, Copenhagen, Denmark

Ravn, H. 2001, Balmorel: A Model for Analyses of the Electricity and CHP Markets in the Baltic Sea Region. ElkraftSystem, Denmark

Ravn, H. 2009, Web page Balmorel - A Model for Analyzing the Energy Sector in an International Perspective. www.balmorel.com

RenoSam. Still more efficient waste treatment - Benchmarking 2006. Stadig mere effektiv affaldsbehandling. 2006.

Rostrup-Nielsen, T., Nielsen, P. E. H., Joensen, F., Madsen, J. 2007, Polygeneration - Integration of Gasoline Synthesis and IGCC Power Production Using Topsoe's TIGAS Process, in: Sønderberg Petersen, L., Larsen, H. (eds.), Risø international energy conference 2007, RisøDTU, Risø, Denmark.

Sahlin, J., Knutsson, D., Ekvall, T. 2004, Effects of planned expansion of waste incineration in the Swedish district heating systems, Resources, Conservation and Recycling, vol. 41, no. 4, pp. 279-292.

Salvia, M., Cosmi, C., Macchiato, M., Mangiamele, L. 2002, Waste management system optimisation for Southern Italy with MARKAL model, Resources, Conservation and Recycling, vol. 34, no. 2, pp. 91-106.

Sundberg, J., Olofsson, M., Sahlin, J. 2004, Evaluating waste incineration as treatment and energy recovery method from an environmental point of view. Profu, Mölndal, Sweden

Villanueva, A., Wenzel, H. 2007, Paper waste - Recycling, incineration or landfilling? A review of existing life cycle assessments, Waste Management, vol. 27, no. 8, p. S29-S46.

Winkler, J., Bilitewski, B. 2007, Comparative evaluation of life cycle assessment models for solid waste management, Waste Management, vol. 27, no. 8, pp. 1021-1031. 
Baky, A. \& Eriksson, O. Systems Analysis of Organic Waste Management in Denmark. Environmental Project no. 822, 2003. 2003. Danish Environmental Agency, Copenhagen

Ball, M., Wietschel, M., \& Rentz, O. 2007, Integration of a hydrogen economy into the German energy system: an optimising modelling approach, International Journal of Hydrogen Energy, vol. 32, no. 10-11, pp. 1355-1368.

Cherubini, F., Bargigli, S., \& Ulgiati, S. 2008, Life cycle assessment of urban waste management: Energy performances and environmental impacts. The case of Rome, Italy, Waste Management, vol. 28, no. 12, pp. 2552-2564.

Cosmi, C., Cuomo, V., Macchiato, M., Mangiamele, L., Masi, S., \& Salvia, M. 2000, Waste management modeling by MARKAL model: A case study for Basilicata Region, Environmental Modeling \& Assessment, vol. 5, no. 1, pp. 19-27.

Danish Energy Agency 2008, Danish Energy Statistics 2007. Danish Energy Agency, Copenhagen, Denmark

Danish Energy Authority. Energiproducenttælling 2006 (Energy Producer Statistics 2006). 23-42008. Danish Energy Authority, Copenhagen, Denmark

Danish Energy Authority. Guidelines in socio-economic analysis in the field of energy. 2009. Danish Energy Authority, Copenhagen

Ekvall, T., Assefa, G., Bjorklund, A., Eriksson, O., \& Finnveden, G. 2007, What life-cycle assessment does and does not do in assessments of waste management, Waste Management, vol. 27, no. 8, pp. 989-996.

Ekvall, T. \& Weidema, B. P. 2004, System boundaries and input data in consequential life cycle inventory analysis, International Journal of Life Cycle Assessment, vol. 9, no. 3, pp. 161-171.

Eriksson, O., Finnveden, G., Ekvall, T., \& Bjorklund, A. 2007, Life cycle assessment of fuels for district heating: A comparison of waste incineration, biomass- and natural gas combustion, Energy Policy, vol. 35, no. 2, pp. 1346-1362.

Finnveden, G., Bjorklund, A., Reich, M. C., Eriksson, O., \& Sorbom, A. 2007, Flexible and robust strategies for waste management in Sweden, Waste Management, vol. 27, no. 8, p. S1-S8.

Finnveden, G. 1999, Methodological aspects of life cycle assessment of integrated solid waste management systems, Resources, Conservation and Recycling, vol. 26, no. 3-4, pp. 173-187.

Fruergaard, T. 2008, Assessment of waste resources for energy production - Fractions, quantities, segregation potentials and energy content. Danish Technical University, Department of Environmental Engineering, Lyngby, DK

Holmgren, K. \& Henning, D. 2004, Comparison between material and energy recovery of municipal waste from an energy perspective - A study of two Swedish municipalities, Resources Conservation and Recycling, vol. 43, no. 1, pp. 51-73.

Jensen, S. G. \& Meibom, P. 2008, Investments in liberalised power markets: Gas turbine investment opportunities in the Nordic power system, International Journal of Electrical Power \& Energy Systems, vol. 30, no. 2, pp. 113-124. 
Karlsson, K. \& Meibom, P. 2008, Optimal investment paths for future renewable based energy systems--Using the optimisation model Balmorel, International Journal of Hydrogen Energy, vol. 33, no. 7, pp. 1777-1787.

Kirkeby, J. T., Birgisdottir, H., Hansen, T. L., Christensen, T. H., Bhander, G. S., \& Hauschild, M. 2006, Evaluation of environmental impacts from municipal solid waste management in the municipality of Aarhus, Denmark (EASEWASTE), Waste Management \& Research, vol. 24, no. 1, pp. 16-26.

Klang, A. B., Vikman, P. +., \& Bratteb ${ }^{\circ}$, H. 2008, Sustainable management of combustible household waste--Expanding the integrated evaluation model, Resources, Conservation and Recycling, vol. 52, no. 8-9, pp. 1101-1111.

Knutsson, D., Sahlin, J., Werner, S., Ekvall, T., \& Ahlgren, E. O. 2006, HEATSPOT--a simulation tool for national district heating analyses, Energy, vol. 31, no. 2-3, pp. 278-293.

Ljunggren Soderman, M. 2003, Recovering energy from waste in Sweden--a systems engineering study, Resources, Conservation and Recycling, vol. 38, no. 2, pp. 89-121.

Mathiesen, B. V., Münster, M., \& Fruergaard, T. 2009, Uncertainties related to the identification of the marginal energy technology in consequential life cycle assessments, Journal of Cleaner Production, vol. 17, no. 15, pp. 1331-1338.

Münster, M. \& Lund, H. Use of waste for heat, electricity and transport--Challenges when performing energy system analysis. 2008. Energy In Press, Corrected Proof

Münster, M. \& Lund, H. 2009, Comparing Waste-to-Energy technologies by applying energy system analysis, Waste Management, vol. In Press, Corrected Proof.

Münster, M. \& Meibom, P. 2009, "Optimal Use of Waste in the Future Energy System," in Energy System Analysis of Waste to Energy Technologies, Aalborg University, Aalborg, Denmark.

Ramboll 2008, Vurdering af mængden af forbrændingsegnet affald i Danmark (Assessment of the amount of incinerable waste in Denmark) 834-071572. waste denmark, Copenhagen, Denmark

Ravn, H. Balmorel - A Model for Analyzing the Energy Sector in an International Perspective. 2009.

Sahlin, J., Knutsson, D., \& Ekvall, T. 2004, Effects of planned expansion of waste incineration in the Swedish district heating systems, Resources, Conservation and Recycling, vol. 41, no. 4, pp. 279-292.

Salvia, M., Cosmi, C., Macchiato, M., \& Mangiamele, L. 2002, Waste management system optimisation for Southern Italy with MARKAL model, Resources, Conservation and Recycling, vol. 34, no. 2, pp. 91-106.

Sundberg, J., Olofsson, M., \& Sahlin, J. 2004, Evaluating waste incineration as treatment and energy recovery method from an environmental point of view. Profu, Mölndal, Sweden

Villanueva, A. \& Wenzel, H. 2007, Paper waste - Recycling, incineration or landfilling? A review of existing life cycle assessments, Waste Management, vol. 27, no. 8, p. S29-S46. 
Winkler, J. \& Bilitewski, B. 2007, Comparative evaluation of life cycle assessment models for solid waste management, Waste Management, vol. 27, no. 8, pp. 1021-1031. 
FIGURES

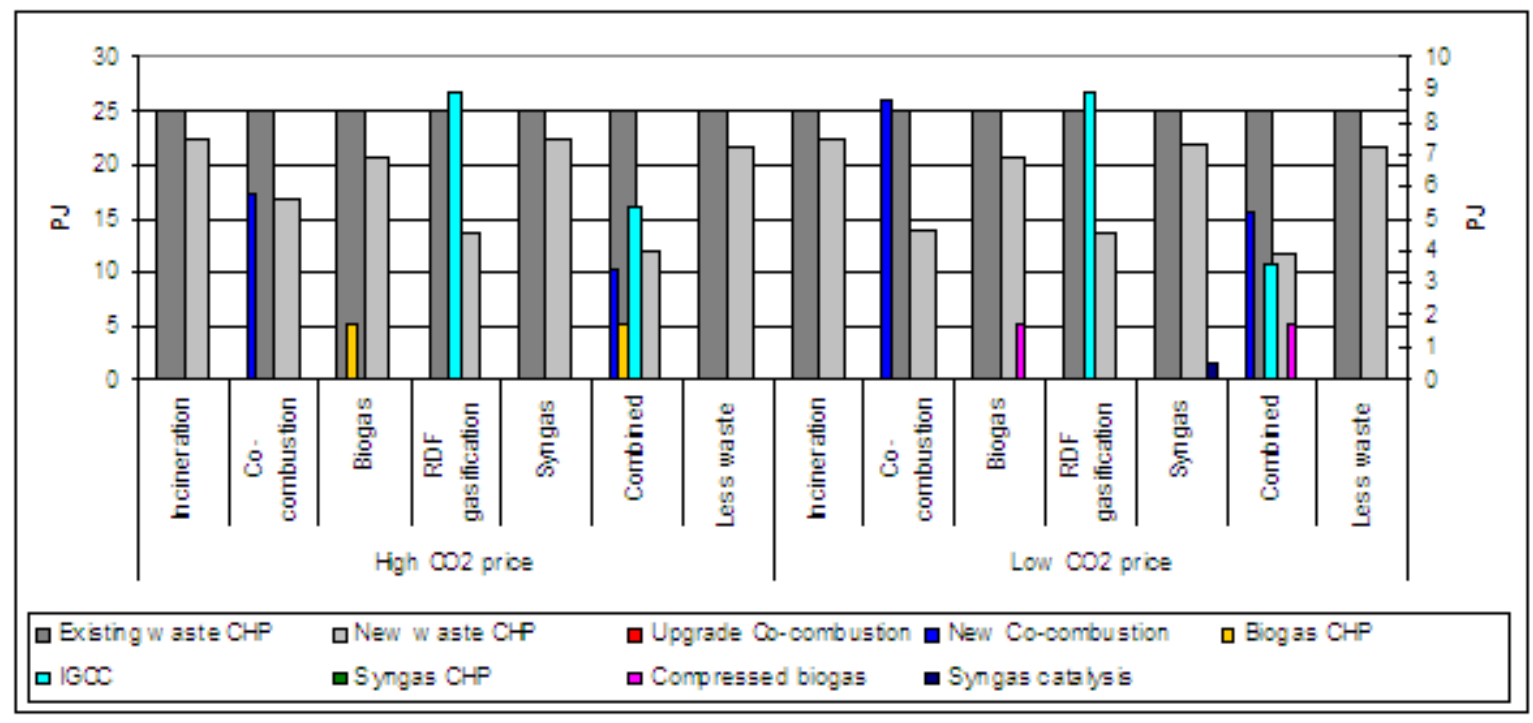

Figure 1. Use of waste for energy in Denmark. Waste incineration CHP is shown on the left axis and the remaining $\mathrm{WtE}$ technologies on the right

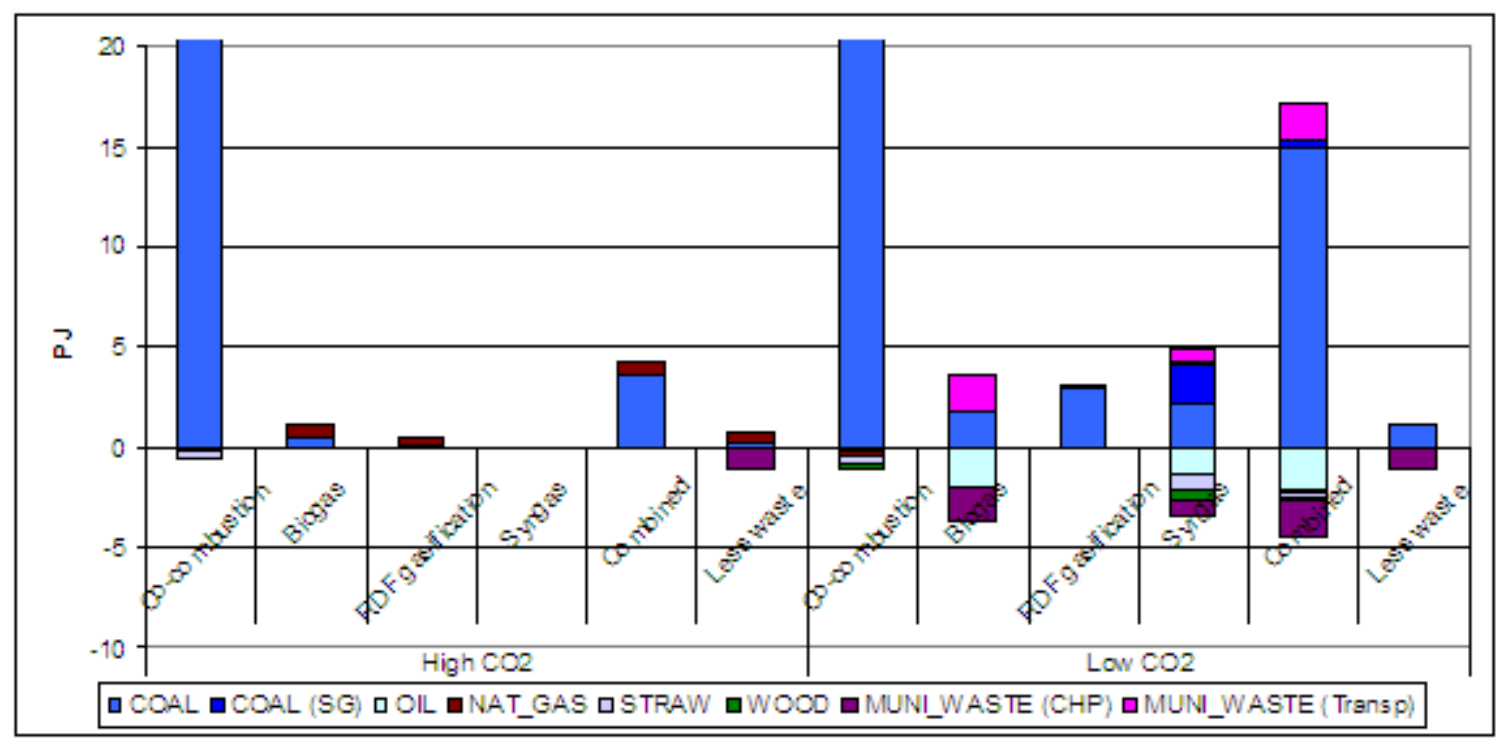

Figure 2. Changed fuel use for Denmark concerning all technologies, when compared to the Incineration alternative with high or low CO2 prices respectively (max 20 PJ shown) 


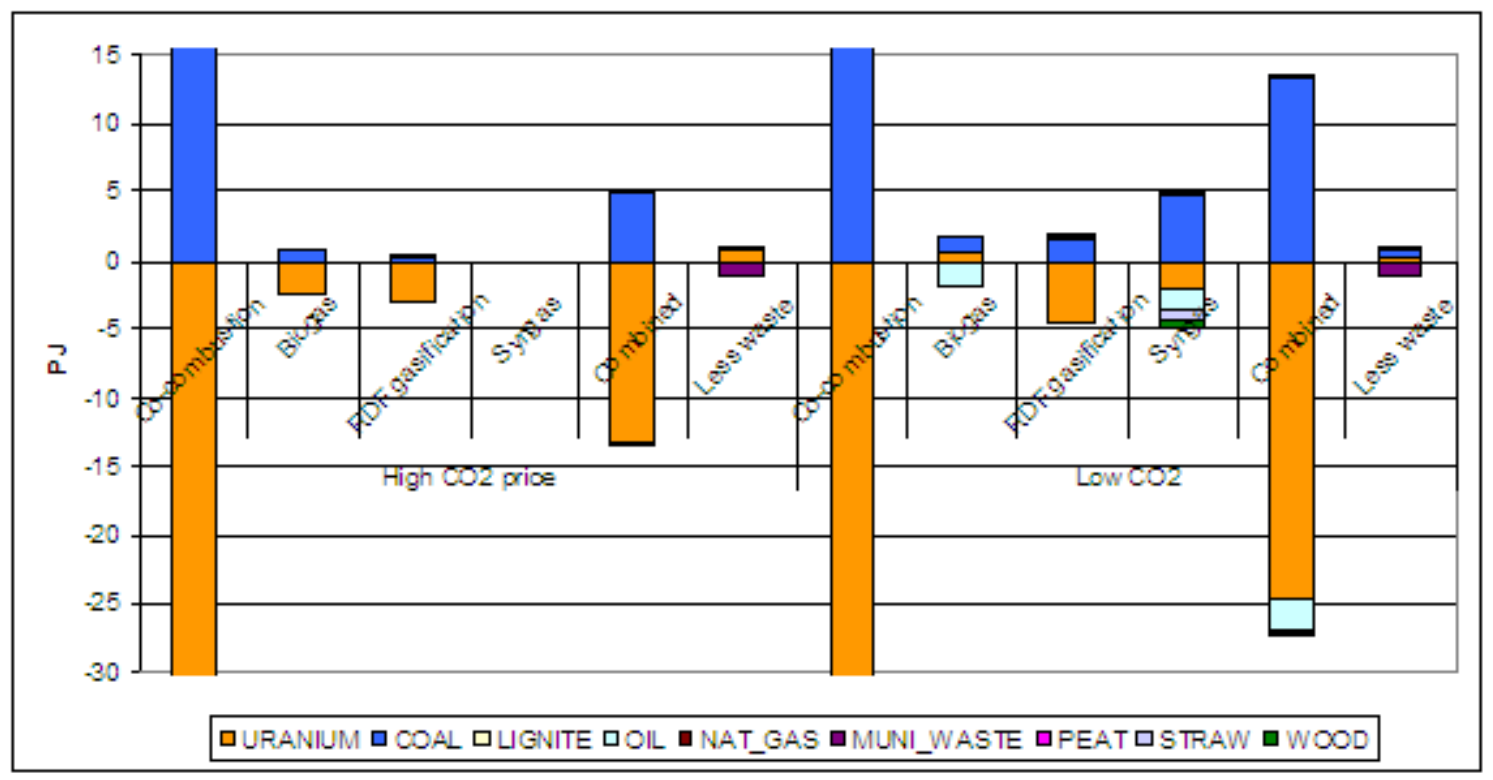

Figure 3. Changed fuel use for the whole region for all technologies, when compared to the Incineration alternative with high or low CO2 prices respectively (max 15 PJ and min -30 PJ shown)

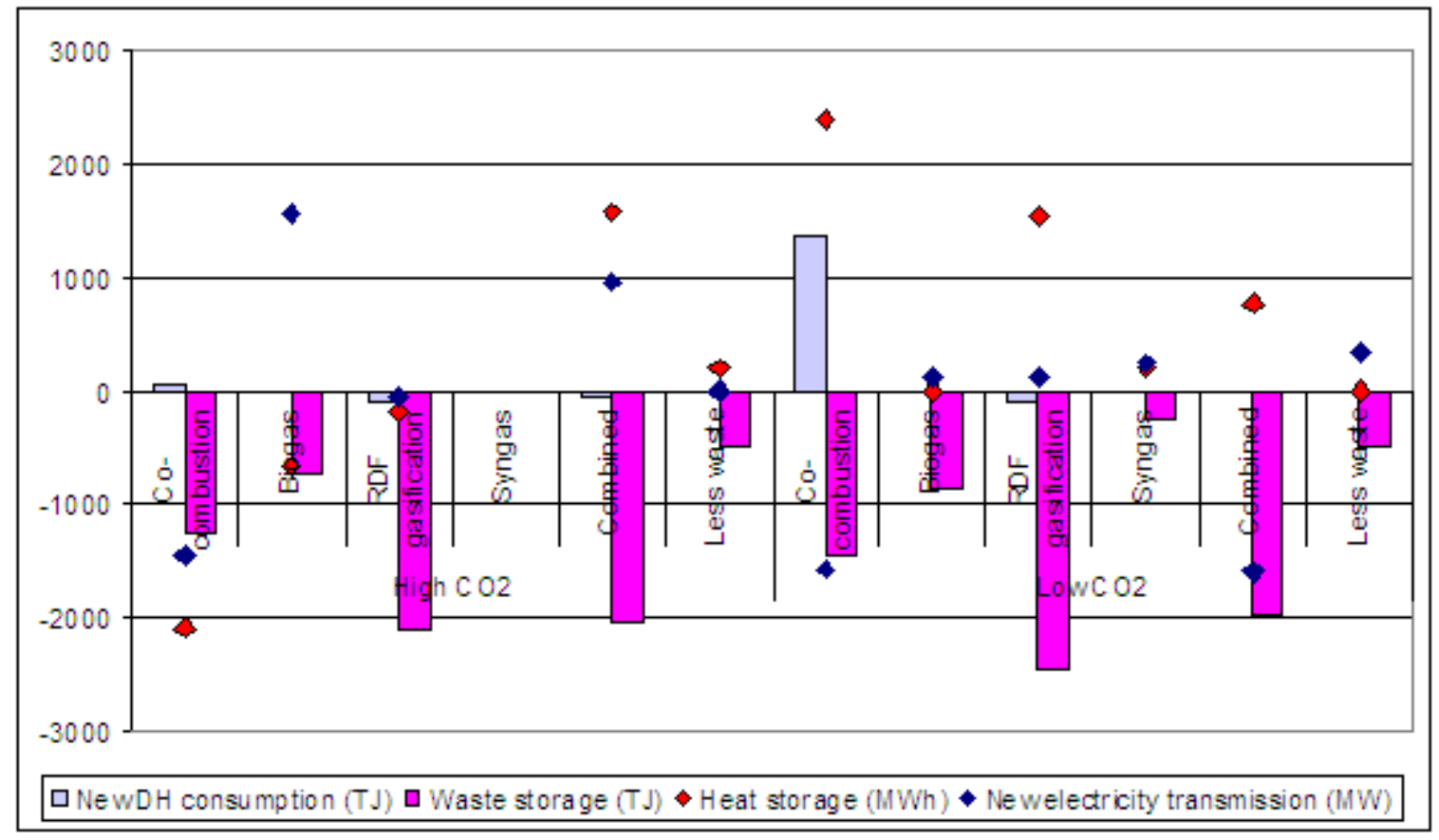

Figure 4. Changes in new DH consumption owing to investments in DH networks, electricity transmission and heat storage as well as use of central waste storage compared to the Incineration alternative. 


\section{TABLES}

Table 1 Efficiencies and costs of WtE technologies

\begin{tabular}{|c|c|c|c|c|c|c|c|c|c|}
\hline & Fuel & $\begin{array}{l}\text { Fuel } \\
\text { eff. }\end{array}$ & $C B$ & $C V$ & Inv cost & $\begin{array}{c}\text { VO\&M } \\
\text { cost }\end{array}$ & $\begin{array}{c}\text { FO\&M } \\
\text { cost }\end{array}$ & $\begin{array}{l}\text { Life- } \\
\text { time }\end{array}$ & Source \\
\hline & & & & & $\begin{array}{c}\text { MEUR/ } \\
\text { MWel }\end{array}$ & $\begin{array}{c}\text { EUR/ } \\
\text { MWhel }\end{array}$ & $\begin{array}{l}\text { kEUR/ } \\
\text { MWel }\end{array}$ & Years & \\
\hline $\begin{array}{l}\text { Mixed waste gasification } \\
\text { (Syngas) }\end{array}$ & $\begin{array}{l}\text { Coal/ Mixed } \\
\text { waste }\end{array}$ & 0.78 & & & 0.69 & & 43.4 & 20 & $a / b / c$ \\
\hline $\begin{array}{l}\text { Combined cycle, back } \\
\text { pressure (CHP) }\end{array}$ & Syngas & 1.04 & 1.31 & & 0.89 & 2.8 & 10.2 & 20 & $\mathrm{a} / \mathrm{b} / \mathrm{d} / \mathrm{e}$ \\
\hline $\begin{array}{l}\text { Syngas Catalysis } \\
\text { (Transport) }\end{array}$ & Syngas & 0.79 & & & 0.13 & & 81.7 & 20 & $\mathrm{a} / \mathrm{b}$ \\
\hline $\begin{array}{l}\text { Integrated gasification and } \\
\text { combined cycle, extraction } \\
\text { (CHP) }\end{array}$ & $\mathrm{RDF}$ & 0.49 & 0.93 & 0.13 & 2.06 & & 92.9 & 20 & $\mathrm{a} / \mathrm{b} / \mathrm{c}$ \\
\hline $\begin{array}{l}\text { Gasification and DME } \\
\text { production (Transport) }\end{array}$ & $\mathrm{RDF}$ & 0.67 & & & 1.98 & & 118.6 & 20 & c \\
\hline $\begin{array}{l}\text { Biogas Plant and Engine, } \\
\text { back pressure (CHP) }\end{array}$ & $\begin{array}{l}\text { Organic } \\
\text { waste and } \\
\text { manure } \\
\end{array}$ & 0.60 & 0.8 & & 1.86 & & 170.8 & 20 & c \\
\hline $\begin{array}{l}\text { Biogas Plant incl. cleaning } \\
\text { and upgrading (Transport) }\end{array}$ & $\begin{array}{l}\text { Organic waste } \\
\text { and manure }\end{array}$ & 0.56 & & & 1.93 & & 170.8 & 20 & c \\
\hline $\begin{array}{l}\text { Co-combustion upgrade, } \\
\text { steam turbine, extraction } \\
\text { (CHP) }\end{array}$ & $\begin{array}{l}\text { Coal/ RDF/ } \\
\text { Straw }\end{array}$ & $\begin{array}{l}0.37- \\
0.47\end{array}$ & $\begin{array}{c}0.59- \\
4.76\end{array}$ & $0.15-0.2$ & 0.15 & $2.7 / 4.5$ & 56.4 & 30 & e/f/g \\
\hline $\begin{array}{l}\text { Co-combustion steam } \\
\text { turbine, extraction (CHP) }\end{array}$ & Coal/ RDF & $\begin{array}{l}0.53 / \\
0.52 \\
\end{array}$ & $\begin{array}{l}0.95 / \\
0.94 \\
\end{array}$ & 0.15 & 1.39 & 4.5 & 23.5 & 30 & e \\
\hline $\begin{array}{l}\text { Incineration steam turbine, } \\
\text { back pressure (CHP) }\end{array}$ & Mixed waste & 0.97 & 0.37 & & 5.44 & 20.3 & 217.8 & 30 & e \\
\hline
\end{tabular}

a (DONG Energy 2007)

b (Rostrup-Nielsen et al. 2007)

c (EUCAR et al. 2007)

d (Ahrenfeldt et al. 2005) e (Danish Energy Authority et al. 2005)

f (Møller et al. 2008)

g (Danish Energy Authority 2008b) 
Table 2. Projected fuel prices in 2025, lower heating values and $\mathrm{CO}_{2}$ content of fuels

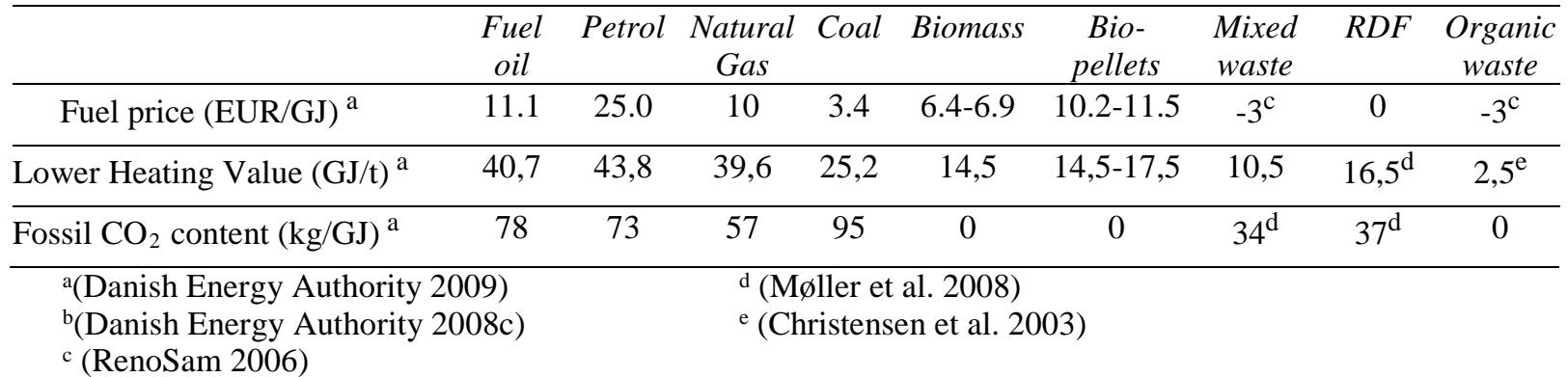


Table 3. Projected energy demands and remaining electricity production capacity in the Nordic countries and Germany

\begin{tabular}{lccccc}
\hline & $D K$ & $D E$ & $F I$ & $N O$ & $S E$ \\
\hline $\begin{array}{l}\text { Electricity demand } \\
\text { (TWh)* }\end{array}$ & $35^{\mathrm{a}}$ & $543^{\mathrm{b}}$ & $106^{\mathrm{b}}$ & $145^{\mathrm{b}}$ & $148^{\mathrm{b}}$ \\
\hline $\begin{array}{l}\text { District heat demand } \\
\text { (PJ)* }\end{array}$ & $67^{\mathrm{a}}$ & $337^{\mathrm{c}}$ & $266^{\mathrm{d}}$ & $9^{\mathrm{c}}$ & $166^{\mathrm{c}}$ \\
\hline $\begin{array}{l}\text { Remaining electricity } \\
\text { production capacity and } \\
\text { main fuel (GW) }\end{array}$ & $\begin{array}{c}5.7 \\
\text { (Coal, wind, } \\
\text { ngas) }\end{array}$ & $\begin{array}{c}\text { (Wind, coal, } \\
\text { hydro) }\end{array}$ & $\begin{array}{c}\text { (Nuclear, hydro, (Hydro, wind) } \\
\text { oil) }\end{array}$ & $\begin{array}{c}\text { (Hydro, nuclear, } \\
\text { wind) }\end{array}$ \\
\hline
\end{tabular}

* Excluding transmission losses

c (Danish Energy Authority 2007)

a (Danish Energy Authority 2008a) ～ (Kiviluoma \& Meibom 2009)

b (Papageorgi 2006) 
Table 4 Fuel use in the whole region. Totals for Incineration alternatives and differences compared to these for the remaining alternatives.

\begin{tabular}{|c|c|c|c|c|c|c|c|c|c|c|c|}
\hline & 2 & $\begin{array}{l}\sum \\
\text { 号 } \\
\text { 怘 } \\
\text { 号 }\end{array}$ & 它 & 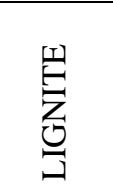 & 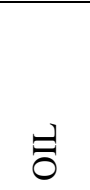 & 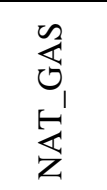 & 党点 & 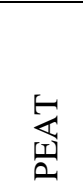 & 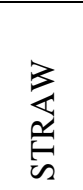 & $\begin{array}{l}0 \\
0 \\
3\end{array}$ & 学 \\
\hline \multirow{7}{*}{$\begin{array}{l}\text { High } \\
\text { CO2 p }\end{array}$} & Incineration & 3826,12 & 1606,09 & 107,61 & 0,90 & 103,40 & 239,05 & 6,76 & 7,23 & 159,28 & 660,16 \\
\hline & $\begin{array}{l}\text { Co- } \\
\text { combustion }\end{array}$ & $-36,48$ & 20,41 & 0,31 & $-0,06$ & $-0,39$ & 0,00 & 0,01 & $-0,27$ & 0,00 & 0,00 \\
\hline & Biogas & $-2,33$ & 0,64 & 0,00 & 0,00 & 0,01 & 0,00 & 0,00 & 0,00 & 0,01 & 0,00 \\
\hline & $\begin{array}{l}\text { RDF } \\
\text { gasification }\end{array}$ & $-3,04$ & 0,30 & $-0,05$ & 0,00 & $-0,04$ & 0,00 & 0,00 & 0,04 & 0,04 & 0,00 \\
\hline & Syngas & & & & & & & & & & \\
\hline & Combined & $-13,29$ & 4,84 & $-0,07$ & $-0,02$ & $-0,09$ & 0,00 & 0,01 & $-0,03$ & 0,04 & 0,00 \\
\hline & Less waste & 0,62 & 0,24 & 0,03 & 0,00 & 0,04 & $-1,00$ & 0,00 & 0,00 & 0,01 & 0,00 \\
\hline \multirow[t]{2}{*}{$\begin{array}{l}\text { Sens- } \\
\text { itivity }\end{array}$} & $\begin{array}{l}\text { Incineration } \\
\text { - no nuclear } \\
\end{array}$ & $-2536,95$ & 1283,36 & 1,68 & $-0,03$ & 25,15 & 0,01 & $-0,60$ & 1,19 & $-0,38$ & 218,74 \\
\hline & $\begin{array}{l}\text { Combined - } \\
\text { no nuclear }\end{array}$ & $-0,06$ & $-2,03$ & $-1,34$ & 0,01 & 0,38 & 0,00 & 0,00 & 0,06 & $-0,01$ & $-1,71$ \\
\hline \multirow[t]{7}{*}{$\begin{array}{l}\text { Low } \\
\text { CO2 p }\end{array}$} & Incineration & 3299,51 & 1937,86 & 116,20 & 0,92 & 103,11 & 239,04 & 6,98 & 7,09 & 158,62 & 660,16 \\
\hline & $\begin{array}{l}\text { Co- } \\
\text { combustion }\end{array}$ & $-64,62$ & 35,60 & 0,14 & $-0,08$ & $-0,86$ & 0,00 & 0,06 & $-0,51$ & $-0,12$ & 0,00 \\
\hline & Biogas & 0,52 & 1,14 & 0,00 & $-1,96$ & 0,02 & 0,00 & 0,00 & 0,00 & 0,01 & 0,00 \\
\hline & $\begin{array}{l}\text { RDF } \\
\text { gasification }\end{array}$ & $-4,60$ & 1,53 & 0,16 & 0,01 & 0,03 & 0,00 & 0,00 & 0,03 & 0,04 & 0,00 \\
\hline & Syngas & $-2,11$ & 4,73 & 0,04 & $-1,41$ & 0,07 & 0,00 & 0,00 & $-0,66$ & $-0,65$ & 0,00 \\
\hline & Combined & $-24,70$ & 13,27 & 0,07 & $-2,23$ & 0,06 & 0,00 & 0,00 & $-0,20$ & $-0,12$ & 0,00 \\
\hline & Less waste & 0,05 & 0,81 & 0,01 & 0,00 & 0,04 & $-1,00$ & 0,00 & 0,00 & 0,00 & 0,00 \\
\hline
\end{tabular}


Table 5 Changed $\mathrm{CO}_{2}$ emissions and changed costs compared to the Incineration alternative

\begin{tabular}{clcccc}
\hline Scenario & Alternative & $\mathrm{CO}_{2} \mathrm{DK}(\mathrm{Mt})$ & $\mathrm{CO}_{2}$ All $(\mathrm{Mt})$ & Cost All (MEUR) & Cost All (MEUR/PJ) \\
\hline High $\mathrm{CO}_{2}$ price & Co-combustion & 2,82 & 1,94 & -30 & -5 \\
\hline & Biogas & 0,08 & 0,06 & -15 & -9 \\
\hline & RDF gasification & 0,03 & 0,02 & -34 & -4 \\
\hline & Syngas & & & & -6 \\
\hline Combined & 0,39 & 0,45 & -60 & -3 \\
\hline Low $\mathrm{CO}_{2}$ price & Less waste & 0,01 & $-0,01$ & -3 & -5 \\
\hline & Co-combustion & 4,79 & 3,35 & -41 & -11 \\
\hline & Biogas & $-0,05$ & $-0,05$ & -20 & -4 \\
\hline & RDF gasification & 0,28 & 0,16 & -35 & -2 \\
\hline & Syngas & 0,29 & 0,34 & -1 & -6 \\
\hline & Combined & 1,20 & 1,18 & -68 & -3 \\
\hline
\end{tabular}

